policies, one suspects the timing of

A Dubious Expediency: How Race Preferences Damage Higher Education, eds. Gail Heriot, Maimon Schwarzschild, Encounter, 2021, pp. 336, \$21.68 hardcover.

\section{On Dubious Race Preferences}

\section{R. Lawrence Purdy}

A Dubious Expediency is a new collection of essays addressing a decades-old and still hotly debated topic. True to its subtitle, How Race Preferences Damage Higher Education, the eight essays are filled with cogent arguments explaining why race preference admissions policies in higher education should come to an end. Given that the U. S. Supreme Court is currently considering whether to review a high-profile case $^{1}$ which could well decide the fate of such this release is no accident. In fact, one of the essays ${ }^{2}$ dives headlong into the reasons why the Court should (1) grant the Petition for Certiorari filed by Asian-American plaintiffs who sued Harvard College over its practice of racially discriminating against Asian American applicants; and, (2) overturn the nearly two-decades-old (supposedly “temporary”) precedent established in Grutter v. Bollinger ${ }^{3}$ and reaffirmed in Fisher $v$. University of Texas at Austin (hereinafter Fisher II) that currently permits Harvard and other colleges and universities to consider an applicant's race during the admissions process.

Of course, it is obvious that the use of such policies in the zero-sum admissions game inevitably results in some students being awarded a bonus, and thus receiving an offer of admission, solely because of their preferred race; and, conversely, other applicants find themselves rejected solely because of their un-preferred race. A

1 See Petition for Writ of Certiorari filed February 25, 2021 in Students For Fair Admissions, Inc. v. President \& Fellows of Harvard College (hereinafter SFFA).

2 "Race Preferences and Discrimination Against Asian Americans in Higher Education," co-authored by Lance Izumi and Rowena Itchon.

3539 U. S. 306 (2003). While Grutter arguably imposed a twenty-five-year sunset clause on the use of such blatantly discriminatory policies, see 539 U. S. at 343, a more recent decision, Fisher v. University of Texas at Austin, 136 S Ct. 2198 (2016) ("Fisher II"), reaffirmed Grutter without any mention of Grutter's judicially-imposed time limit.

R. Lawrence Purdy is a lawyer in private practice in Minneapolis, Minnesota; larry.purdy@icloud.com. Between 1997 and 2003 he served as one of the trial counsel for the plaintiffs who challenged the race preference admissions policies at the University of Michigan in the Supreme Court (Grutter and Gratz). Mr. Purdy is the author of Getting Under the Skin of Diversity: Searching for the Color-Blind Ideal (Robert Lawrence Press, 2008) and, for the website of the National Association of Scholars, "The Critical Question Involves 'Critical Mass,'" (September 30, 2013). 
clearer example of racial discrimination is hard to imagine.

While the university admissions policies examined in Grutter and Fisher narrowly survived ${ }^{4}$ the equal protection guarantees contained in the Fourteenth Amendment as well as the express prohibition against racial discrimination found in the language of Title VI of the Civil Rights Act of 1964 , the paper-thin legality of race preferences is not the main target of this collection of essays. Indeed, with the exception of Professor Heriot's lengthy personal contribution, ${ }^{5}$ the rest of the authors spend precious few words arguing over the legal precedents of Grutter and Fisher II. Instead, they devote the bulk of their energy to explaining why, legality aside, race preference policies result in numerous injustices and do actual damage to the entire system of higher education, including to the administrators, teachers, and the students themselves. The essays, like the contributors themselves, are, in a word, diverse. The nine contributors include two sitting members of the United States Commission on Civil Rights. ${ }^{6}$ In addition to the editors, University of San Diego Law School professors Gail Heriot and Maimon Schwarzschild, three others have devoted a substantial portion of their professional careers to education. ${ }^{7}$ The remaining contributors include a bestselling author and Fellow at the Manhattan Institute $^{8}$ as well as two others with a long history of work in the area of public policy. ${ }^{9}$

Interestingly, the consensus regarding the damage caused by race preferences is arrived at by a

4 Grutter was decided 5-4 with strong dissents authored by Chief Justice Rehnquist, and Justices Scalia, Thomas, and Kennedy. Fisher II was decided 4-3 in a case in which Justice Kennedy, writing for a different majority thirteen years after Grutter, inexplicably abandoned the principles he earlier had articulated in Grutter. (Note: Only seven justices decided Fisher /l because Justice Scalia died before the case was decided and his replacement had not yet been seated. Justice Kagan had recused herself.)

5 Professor Heriot's contribution is the title essay "A Dubious Expediency" (19-86). The title itself is drawn from the language of liberal icon, California Supreme Court Justice Stanley Mosk. Writing for the majority in the California Supreme Court in Bakke v. UC Regents, 18 Cal. 3 ${ }^{\text {rd }} 36,62-63$ (1976), Justice Mosk's language perfectly captures the fundamental legal argument against race preference admissions: "To uphold the [argument for race-preferential admissions] would call for the sacrifice of principle for the sake of dubious expediency and would represent a retreat in the struggle to assure that each man and woman shall be judged based on individual merit alone, a struggle which has only lately achieved success in removing legal barriers to racial equality." (DE at 19-20, emphasis added.)

6 Lawyer Peter N. Kirsanow and Professor Heriot are members of the Commission. In addition, Professor Schwarzschild is a member of the California State Advisory Committee to the Commission.

7 John M. Ellis is University of California-Santa Cruz Professor Emeritus of German Literature; Lance Izumi is a former president of the board of governors of the California Community Colleges and a former commissioner on the California Postsecondary Education Commission; and National Association of Scholars President Peter W. Wood is the former provost of The King's College in NYC and a former tenured member of the anthropology department at Boston University.

8 Heather Mac Donald is a contributing editor of City Journal and a frequent commentator on issues surrounding "diversity."

9 Rowena M. Itchon and Carissa Mulder. More complete bios of the contributors are found on pages 265267. 
collection of professionals who did not enter the debate universally opposed, in principle, to their use in the setting of higher education. For example, the very first essay by John M. Ellis (“Starting Down the Slippery Slope”) offers a candid assessment of how a good-faith willingness on the part of college and university deans to depart ever so slightly from "principle" in order to expand opportunities for higher education to underrepresented minority students proved disastrous. Though he never quite admits it, Ellis presents a self-portrait of an educator and former university dean who, if not necessarily an avid proponent for the use affirmative action (i.e., the use of race preference admissions) in the early years, was at a minimum agnostic when it came to the topic. He describes the almost universal early view held by most educators that "when it began, affirmative action [in the form of racial preferences] seemed so modest and circumscribed, so limited in scope and so well-intended, that it was impossible to imagine the damage it would do," but eventually concludes, "[i]f there is one moral to this story, it is that there is no such thing as a little sin and no such thing as a small departure from principle." (8)
In the end, Ellis describes the loss of his agnosticism via painful exit interviews he personally conducted with failed black Ph.D. candidates. His conclusion? The damage done to these particular black students by admitting them via a process that failed to apply the same color-blind standards to every applicant, was "cruelly destructive for the [individual Ph.D. candidates] concerned" (18); and not only to them but to the university professors and faculty advisors-black and white-who were left to deal with the emotional carnage created by these policies. These experiences converted this early and admittedly willing practitioner of "affirmative action" into a firm opponent of these policies.

Following Ellis's essay is editor Gail Heriot's lengthy contribution that contains a broad-ranging discussion covering numerous topics including the "mismatch" theory created by race preference admissions. Her contributions are essentially a macro-discussion of many of the topics addressed on a more personal level by Professor Ellis, as well as several of the topics raised by the other authors. In addition, she provides a detailed history of the positive effects once race preference admissions were dismantled, as occurred in the State of California following the passage of Proposition 209. All told, Professor Heriot has a 
hand in almost 100 out of the total of 261 pages contained in this collection, a reflection of her extensive devotion over the years to this subject.

Among the more fascinating essays is the one authored by former Boston University anthropology professor, Peter W. Wood, now the president of the National Association of Scholars. Among the many provocative issues he raises in "Diversity's Descent" is that the original diversity rationale first mentioned in 1978 by [U. S. Supreme Court] Justice Lewis Powell in the landmark Bakke case rested on "the idea that education is enhanced for everyone by the opportunities to learn from people unlike ourselves." (99) But according to Wood, diversity has, from the start, had a double-and incongruentmeaning depending upon the audience. He notes, for example, that when "diversity is marketed to white students as a life-enhancing and educationally enriching encounter with students of other races and ethnicities," it assumes the full integration of all the students. "But when colleges speak of diversity to minority students, that integrationist rhetoric and imagery disappears and is replaced by strong assurances that the university has an abundance of students in their own racial group and lots of well-funded opportunities to bond with people just like you." (99-100)

This latter point becomes the focus of the essay "Segregation Now," authored by Professor Heriot's colleague on the Civil Rights Commission, Peter N. Kirsanow. Using his own personal experience as an undergraduate student at Cornell University beginning in 1972, Mr. Kirsanow addresses the discomfiting phenomenon of the re-segregation currently taking place on many university campuses where racial identity has been elevated via the establishment of racially separate dorms and ethnic-themed student centers. The many absurdities created by these and other neo-segregationist policies are in fact antithetical to the purported ideal of integrating students of all races and ethnicities in an effort truly to learn from one another. Mr. Kirsanow is unsparing in his criticisms and points to several examples where unthinkable stereotyping of quite disparate groups, thrown together based solely on a shared skin color, is the end result.

Among all the contributions, perhaps none is more controversial than Heather Mac Donald's offering. Ms. Mac Donald's reputation as a courageous, no-nonsense observer willing to tackle the toughest issues is amply demonstrated in her essay "Breaking the STEM.” When it comes 
to the practical impact of policies that govern the education, training, and hiring policies in our critical science, technology, engineering, and math fields, policies she describes as obsessively focused on diversity rather than demonstrable merit, she strikes hard at the post-higher education consequences of employing race preferences. Ms. Mac Donald recites example after example where diversity policies are now "taking over the hard sciences." She notes that the pressure to increase the representation of women and underrepresented minorities "is changing how science is taught and how scientific qualifications are evaluated." According to Ms. Mac Donald, this bodes ill "for scientific innovation and for American competitiveness.” (144)

Rounding out the contributions is Professor Schwarzschild's discussion of class preferences as a potential-and more socially acceptable-alternative to the use of race. Of course, it remains true that class preferences have often been proposed in large measure because they do not face the same legal (i.e., "strict scrutiny”) obstacles applied to considerations of race. However, Professor Schwarzschild offers a host of provocative reasons why such preferences ought not be adopted.
For lawyers, scholars, and citizens of all stripes interested in the problems presented by race preference admissions in the U. S. system of higher education, A Dubious Expediency is filled with hard facts and sound logic supporting the nine contributors' views that such policies should be ended. 